\title{
Emergent Programmatic Politics and Gradual Demise of Neopatrimonial Tendencies* in Ghana's Electoral Democracy
}

\author{
Isaac Owusu Nsiah \\ Institute of African Studies, University of Ghana, Accra, Ghana \\ Email: isaacnsiah88@gmail.com
}

How to cite this paper: Nsiah, I. O. (2021). Emergent Programmatic Politics and Gradual Demise of Neopatrimonial Tendencies in Ghana's Electoral Democracy. Open Journal of Political Science, 11, 721-738.

https://doi.org/10.4236/ojps.2021.114046

Received: August 22, 2021

Accepted: October 26, 2021

Published: October 29, 2021

Copyright $\odot 2021$ by author(s) and Scientific Research Publishing Inc. This work is licensed under the Creative Commons Attribution International License (CC BY 4.0).

http://creativecommons.org/licenses/by/4.0/

\section{(c) (i) Open Access}

\begin{abstract}
Many countries in Sub-Saharan Africa experienced regime change after the thawing of the cold war. Ghana like other countries in the sub-region, arranged for multiparty elections to displace years of authoritarian rule. After three decades of the second independence, the Africanist literature on electoral politics has generated a debate on the continuity of neopatrimonialism, weak parties and voting intentions largely based on ethnic and clientelistic tendencies. But there have been relevant works that have challenged these narratives. Relying on secondary literature, online news items, centre for democratic development (CDD) pre-election survey and some field notes, this article positions it itself within the ongoing debate by challenging the simplistic narratives how Ghana's democracy has spurred neopatrimonialism, where parties are weak and present no credible policy positions and thus the linkage mechanism between voters and parties are predominantly ethnic and clientelistic. It argues that for about three decades after the third wave of democratization, there is an emergent programmatic politics in Ghana.
\end{abstract}

\section{Keywords}

Programmatic Politics, Ghana, Ethnicity, Clientelism, New Patriotic Party (NPP), National Democratic Congress (NDC)

*Neopatrimonialism is a broad framework in its application to understanding African politics. In the context of this study: first, state agents (political elites or office holders) who occupy some form of centralized or formal position but exercise authority or responsibilities in an informal and personalised manner; mobilization of support through building patron-client networks of dyadic exchange is usually characterized by a sense of obligation, and often also by an unequal balance of power between those involved. These dynamics of networks can be based on clientelism, patronage and ethnicity. Within this work, I only concern myself with electoral politics significantly on citizens' rationale in electoral choices and what political parties also present in exchange for political support. 


\section{Introduction}

Against a backdrop of mired economic development which significantly emanated from politics of Africa's post-colonial state: for example, political instabilities with prevalent coups, weak political institutions, autocracy, neopatrimonial tendencies, such as the concentration of power in the "big man", patronage, clientelistic and spoil politics (Bates, 1981; Aidoo, 2008, Chabal \& Daloz, 1999; Allen, 1995), a development discourse which culminated in a consensus emerged in the late 1980s and early 1990s. That democracy with multiparty elections, strong institutions and good governance were possible solutions to Africa's developmental challenges (Abrahamsen, 2000; World Bank, 1981). Thus, initially, home of three electoral democracies-Botswana, Gambia and Mauritius (Bratton \& Van de Walle, 1997); Ghana, like other sub-Saharan African countries experienced regime change and arranged for multiparty elections in the 1990s after the end of the cold war (Wahman, 2014; Bratton \& Van de Walle, 1997). Since the 1990s, de jure multi-party elections have increased twelvefold in Africa (Cooper, 2018: p. 193). Eight repetitive and highly competitive elections have taken place in Ghana, which the 2020 elections remain the latest. Currently, there are twenty-nine registered political parties in Ghana ${ }^{1}$. More importantly, Ghana's electoral democracy has been touted as a beacon of political excellence and thus a model worth emulating for other sub-Saharan countries. This notwithstanding, existing scholarships present that Ghana's multiparty politics has exacerbated and thus rekindled the flame of neopatrimonialism with its clientelistic, ethnic and populist associates (Lindberg, 2003; Kheefer \& World Bank, 2005; Arthur, 2009; Jockers et al., 2010; Fridy, 2007; Nugent, 2001).

This article critically examines whether Ghana has a consolidated programmatic politics or the political system is still a neopatrimonial one. It contributes to the broader Africanist literature on electoral politics by challenging the predominant and simplistic narratives on theoretical and empirical explanations for Ghana's ethnic and clientelistic posture in party alignment and outcomes during elections. It argues that for about three decades after the third wave of democratization, there is an emergent programmatic politics in Ghana. While some of the sweeping narratives on existing non-programmatic linkages may be true; however, years after democratic consolidation, there has been a significant paradigm shift regarding how programmatic Ghana's body politic has become. This is because as Huntington (1991) and Sartori (1986) project, areas where democracies are in the early stages of development, social cleavages, clientelistic and other non-evaluative tendencies can become the basis of electoral decisions, but as there is a movement towards consolidation and development, voter party linkage primarily based on "Programmaticity" emerges (Kitschelt \& Wilkinson, 2007). This paper largely relies on the secondary literature, online news items, Centre for democratic development (CDD) pre-election survey and some field ${ }^{1}$ This research only sheds light on the New Patriotic Party (NPP) and the National democratic congress (NDC), since they have dominated the political landscape and have alternated political power since the inception of the fourth republic. 
notes in 2016. The next section reviews the literature on electoral politics in Africa to provide an overview of relevant trends on elections, voting intentions and political parties. This, therefore, creates a space for this essay in Ghana to contribute to the literature and challenge the dominant and oversimplified narratives on African politics. Afterward, I provide a conceptual framework for understanding programmatic politics. The final part provides a discussion with significant evidence on the programmatic nature of Ghana's body politic as a relevant critique to the scholarly debates on how neopatrimonialism has taken shape in Ghana's political system.

\section{Electoral Politics in Africa}

African politics reveals varied dynamics especially regarding issues on elections, political parties and voting intentions. For instance, some scholars argue that elections tend to be rigged, with the use of state resources as patronage, politicization of ethnicity and intimidation of opposition parties. Thus, ruling elites in authoritarian states like Cameroun, Burundi, Uganda, Rwanda and Gabon entrench themselves in power (Gyimah-Boadi, 2007; Cheeseman, 2019). Gyimah-Boadi argues further that, elections in Africa suffer from weakness of their own separate from but related to the weakness of political parties (Gyimah-Boadi, 2007, p. 27). On parties in Africa, vast majority of the literature show a pessimistic and disappointing narrative, with respect to the fact that, as Vicky Randall and Lars Svasand put it, "it is much more difficult to find positive accounts of the contributions of political parties in Africa" (Randall \& Svasand, 2002: p. 32). Weaknesses have been the catch-all phrase used to characterize African parties. "weakness" pathology stem from ineffectiveness in organization, widespread diffusion of systems dominated by one party, fragmentation and ineffective opposition, clientelistic networks, ethnic identities as basis for party mobilization, weak policy making capacity of new parties, and the general low level of institutionalization of party systems, strong and hegemonic leadership with poorly developed internal democracy Internal democracy (Fomunyoh, 2001; Olukoshi, 1998; Carothers, 2006; Gyimah-Boadi, 2007; Randall \& Svasand, 2002; Erdmann, 2004; Carbone, 2007; Van de Walle \& Butler, 1999). Van de Walle and Butler (1999) with evidence from Zambia reveal the supposedly insignificance of programmatic appeals in elections as, the National Lima party (NLP) continuously performed poorly with campaign based on programmes. It is then as suggested and concluded by some scholars, that ethno-regional and clientelistic interest are the most rational strategy for political parties in aggregating social interest and mobilizing votes (Horowitz, 2000; Erdmann, 2004).

Given supposedly core feature of African politics-Neopatrimonialism (Chabal \& Daloz, 1999; Bratton \& Van de Walle, 1997), does the African voter deviate from this network of relationship or embrace it? Some scholars advance voting intentions in Africa to surrounded ethnicity and clientelism (Lindberg, 2003; Van de Walle, 2003; Arriola, 2012; Horowitz, 2000). Michael Cowen and 
Liisa Laakso find that, no African study of election study can be seriously complete without an analysis of bribery of voters. Voters own account of elections stressed with much humor, the memory of elections as personal boom-time occasions (Cowen \& Laakso, 2002). Lindberg (2003) finds how electoral democracy has spurred clientelism in Ghana as voters rely on exchange of popular support for material incentives. Wantchekon (2003) studying voting behavior in Benin finds clientelism as predominant in shaping voters' choice and preferences.

However, Chris Allen cautions against overgeneralization in understanding African politics (Allen, 1995). Elections have facilitated the growth of political parties that contest elections freely and competitively where in some cases have resulted in power turnover. Although a continent of strong incumbency advantage (Cheeseman, 2010: p. 140), yet, there have been a handful of opposition victories since 1989, for example, in Benin, Ghana, Madagascar, Mauritius, Nigeria, Liberia, Zambia, Senegal, the Gambia, and Sierra Leone. Recent works (Elischer, 2013; Arriola, 2012; Riedl, 2014; Pitcher, 2012; Whitfield, 2009; Resnick, 2012) as cited by Riedl (2018: p. 43), challenge the many simplistic claims of weak parties in Africa by demonstrating variations in party strength, types of parties and institutionalization that exist across the continent. For example, Anja Osei advances on how institutionalized, well-organized and strong political parties in Ghana are-specifically the NDC and NPP (Osei, 2016). Also, in Mozambique parties appear to be more disciplined and national in character (Pitcher 2012: 161-166 as cited in Osei (2016)). Concerning Gunther and Diamond's classifications-ethnic and clientelistic parties; African parties have conveyed the image of patronage and tribal politics in academic discourse (Gunther \& Diamond 2003; Carbone, 2007). Even to accept this kind of argument, these assertions are made ahistorically - the nature and situation on how ethnicity evolved, shaped and hardened under colonial rule leaves much to be desired (Posner, 2005; Cheeseman, 2018: p. 22). Sebastian Elischer also reveals variations where ethnic parties dominate in some countries, non-ethnic parties have become the norm in others and thus show that African political landscape is more diverse than conventionally assumed (Elischer, 2013). Ichino and Nathan (2016), Osei (2016), Daddieh and Bob-Milliar (2012) explore the interaction between formal and informal party structures, internal party democracy, general distribution of power within parties and how parties adopt policy platforms and appeal to electorates programmatically (Bleck \& Van de Walle, 2011; Cheeseman \& Larmer, 2015) relative to the clientelist myth. For example, in opposition victories in Ghana and Nigeria are attributed to largely state economic level performance and the various perceptions of the national economy influenced the electoral outcome, effective party organisation, credible commitments in broad policies presented by parties (LeVan et al., 2018: p. 433; Bob-Milliar \& Paller, 2018; Owusu Nsiah, 2020a; Gyampo et al., 2017; Owusu Nsiah, 2020b).

On voting intentions, Young (2009) finds that clientelism does not shape voter behaviour in Africa with empirical testing in Kenya and Zambia. Elena Gadjanova also with evidence from Ghana also finds clientelism as not the deter- 
mining factor in popular support (Gadjanova, 2017). Lindberg and Morrison (2008) contend that the African voter is evaluative when it comes to electoral choices. Against this backdrop, this essay with evidence of emergent programmatic politics in Ghana contributes to the above debate as it challenges the dominant narrative on how neopatrimonial framework has taken center stage in Africa's electoral politics.

\section{Programmatic Politics: A Conceptual Framework}

Programmatic politics emerges and develops in a democratic state and theoretically antithetical to clientelist, ethnic and personalistic dynamics. Democracy in its minimalist explanation and procedural terms, demonstrates "the institutional arrangement for arriving at political decisions in which individuals acquire the power to decide by means of a competitive struggle for peoples vote" (Schumpeter, 1942). This exhumes three distinct but connected themes-political parties, elections and voters or citizens. To further explain their interwoven nature and substantiate what programmatic politics means, I shed light on elections briefly. Election functions as a connective mechanism which joins, as described by Kitschelt and Wilkinson (2007: p. 1), principals (citizens, voters) and agents (candidates for electoral office, parties, elected officials). Election gives meaning to the concept of political representation and thus forms the foundation of democratic politics (Dalton, 2014; p. 33; Lindberg, 2006). It determines who manages the affairs of government makes policy (Dalton, 2014). Thus, the selection of leaders, along with the ability to "throw the rascals out" at the next elections, remains the public's penultimate power (Ibid). Therefore, with programmatic politics, the fulfilment of competitive and participatory elections' mandate as the core institution of representative democracy is fully dependent on the linkage mechanisms between voters (electorates) and political parties (Kitschelt, 2000; Lindberg \& Morrison, 2008).

Political parties are relevant institutions and a point of call when discussing programmatic politics. For successful workings of democratic representation and thus devoid of parties, democracy is unthinkable save terms as they are significant and fundamental to the sustenance of democracy (Schattschneider, 1942). James Bryce also adds that "parties are inevitable". No one has shown how representative government could be worked without them' (Bryce, 1921: p. 119). In a programmatic political system, political parties are ideally "programmatic". The international institute for democratic and electoral assistance (IDEA) in one of its publication titled "politics meets policies", Cheeseman and his colleagues find that, programmatic parties are considered to have: a collective policy positions that constitutes a well-structured and stable political program by which the party is publicly known; internal coherence and agreement on a range of policy positions; commitment and the ability to deliver on at least some key programmatic promises when in a position of power; party programs that is the most defining element in how it attracts and engages its members (Cheeseman et 
al., 2014, p. 12). Cheeseman and Paget (2014: p. 75) argue that, programmatic parties generate policies and engage in mobilization of support in terms of vote based on ideologically-driven significant policies. They further contend, unlike clientelistic parties, programmatic ones, do not significantly mobilize support through patron-client networks with the distribution of private and material incentives and thus disassociate from establishing ties between voters based on specific leaders and also based ethnic identities (Ibid). Programmatic parties are organisationally strong and have "reasonably strong ideological or programmatic commitments" (Gunther \& Diamond, 2003: p. 37). Thus, the power behind political parties' electoral success and their long-term survival in the political arena is their party organization (Panebianco, 1988). With a strong organization, parties reap greater success in recruiting quality candidates. This is because; the capacity of the party to function in a competitive electoral system is conditioned to a significant degree on the range and quality of candidates running under the party label (Cotter et al., 1984: p. 7). Strong parties can more effectively formulate policy, cope with environmental challenges, and account rationally for their actions than weak parties (Tavits, 2012: p. 84).

On the other hand, programmatic politics also depends on the sophisticated and evaluative nature (voter behaviour) of the principals (citizens, voters). Oppenheimer and Edwards (2012: pp. 32-33) ask a very thought-provoking question that relate to voters and sustenance of democratic politics that, "how can democracy possibly be successful when it relies on the choices of voters who know so little? This question is relatively imperative since, the purpose of self-rule by representative government would be defeated if voters" behaviour during polls is determined by what some scholars term "non-evaluative rationales" (Lindberg \& Morrison, 2008). Thus, programmatic politics is enhanced when the public has a high degree of political information and sophistication. Evaluative rationales which play a key role in programmatic politics draw inferences from several dimensions. For example, the literature on economic voting-in times of economic progress and stability, citizens vote to renew mandates. But, when there are manifestations of bad economy, they throw the rascals out (Lewis-Beck \& Stemaiger, 2000). The evaluative rationales hinge along two dimensions - the orientation of evaluation in terms of retrospective and prospective of the individual representative or political party. Fiorina (1981) argues that, in retrospective voting, voter rationality, electoral responsibility and issue politics, and shape rational assessment of political parties by individuals before casting of ballots ${ }^{2}$. It deals with assessment of political parties or individuals on how they delivered in terms of governance, whether they were able to mitigate issues confronting the citizenry and also ensured manifestation of their policy intervention promises and issues of the economy. Prospective voting or evaluation deals with the future oriented, carefully calculated and through assessments made on the programmes and policy positions of a political party before the provision ${ }^{2}$ Even though, he considers rationality, he identifies an alternative version development from the Downsian perspective. 
of mandate into government. Evaluative rationales ideally, is what liberal democracy dictates-form of voter-party linkage that holds leaders accountable with respect to policy issues and of the welfare state. Also, it upholds the popular sovereignty theory, as power lies in the bosom of the people and thus thumbs print rulers to promote the collective wellbeing of the state. With this the rationale that should be behind electoral choices must be programmatic (Kitschelt, 2000). As Key (1949) points out, the underlying explanation for evaluative rationales is policy-vote-congruence.

Drawing on the above perspectives, I summarize that "programmatic politics" which takes place in a democratic political system entails the dynamics of activities where parties with ideological congruence (set of beliefs and abstract principles) that inform policy and well-structured cardinal plan that embodies their coherent and consistent party programmes, engages an evaluative or sophisticated citizenry in issue-based politics and thus create voter linkages by making broad national credible commitments to the people in order to obtain mandate to ascend the reins of government.

\section{Ghana: Programmatic or a Neopatrimonial Politics?}

In Ghana's body politic, several arguments have been made against political parties and their links in terms of popular support with citizens and electorates. Some find that parties have weak internal democracy as power and decision-making structures are personalised, centralised and concentrated in the hands of the few (Ayee, 2009). For instance, in terms of primary elections, the few at the top have imposed candidates at the expense of others through compensation. For example, within the NPP, in the 2004 elections, Nana Obiri Boahene, the "party bosses" substituted the preferred parliamentary candidate for the Sunyani East constituency with J. H. Mensah after a compensation made to the former (Ayee, 2009: p. 189). In the 2000 elections a running mate, namely John Atta Mills was selected personally by the dominant figure in the NDC and former president of Ghana, J. J. Rawlings, without the necessary party procedures and structures (ibid). Others contend that, issue-based politics is missing in Ghanaian politics. This is because largely, parties or politicians present no credible commitments of relevant policies for citizens to choose from and thus electorates are attached to and vote for political parties based on ethnic and clientelistic lines (Arthur, 2009; Jockers et al., 2010; Fridy, 2007; Nugent, 2001). In the 2004 elections, the report of the electoral commission made clear that ethnicity was major factor in the elections and a trend which did not differ from the previous elections in 1992, 1996, and 2000 (Electoral Commission of Ghana, 2004: p. 81). This is reinforced as Oquaye (1995: p. 271) finds that the 1992 elections saw a split in new township on tribal lines. "The Zongo dwellers (Northerners) supported Limann; those resident in "Ayigbe town" (Ewes) supported Rawlings while those in Kotwikrom (Akans) supported Adu-Boahen". The two main parties NDC and NPP have laid claim to particular regions. The Volta re- 
gion has returned impressive majority for the NDC, while the Ashanti has never stopped voting for the NPP (Bob-Milliar, 2011). Lindberg (2003) reveals how democracy feeds neopatrimonialism as some Ghanaian members of parliament are engaged in patron-client networks and thus exchange of material incentives for popular support. Whitfield (2009) and Booth et al. (2006) asserts and reinforce that competitive neopatrimonialism argument by positing those policies pursued by Ghanaian politicians reflect a competitive clientelism and populist direction. For example, one scholar argues, the rural electrification project by the NDC under President Rawlings did not make economic sense and thus were deliberately made to target specific groups for votes (Brobbey, 2013). Interestingly, it is also argued that when parties are in power, they deliberately develop programmes to win votes because they cannot sustain the patron-client networks because they are out of power (Aidoo, 2008). But are these sweeping generalizations the realities on the ground regarding Ghana's three decades of multi-party politics? Are parties weak and thus lack the necessary infrastructure to make broad policy commitments? Are the poll data after elections the continuous projection of Ghana's voting behaviour without a cursory and analytical approach into why and how people vote? Do electorates vote; largely based on clientelist and ethnic lines?

Contrary to these dominant assertions, Ghana's multi-party politics has consolidated and thus there is a paradigm shift from the seemingly non-programmatic politics to strong parties and predominantly an issue-based political dynamics and high levels of sophistication and evaluation on the part of the electorates. Based on the conceptual framework that has been laid, I demonstrate and argue for the programmatic nature of Ghana's body politic.

\section{Emergent Programmatic Politics}

In Ghana's open and highly competitive electoral system, the NPP and NDC have demonstrated dominance at the expense of other minor parties (Yobo \& Gyampo, 2015). This has created a system of a defacto "two partysm" (Daddieh \& Bob-Milliar, 2012). More importantly, the reason for the dominance of the NPP and NDC stem from the highly institutionalized party system with low levels of volatility and an alternating majority between these two strong parties (Riedl, 2014: p. 1 as cited in Owusu Nsiah, 2020a). Again, these parties have similarly sized electoral base-they are deeply connected to their constituencies, organize across the national territory to compete in every constituency, mobilize participation during and beyond elections, and aggregate coalitions of diverse citizens and interest (ibid). Issues of intra party politics-decision making, effective organisation and operationalisation of binding measures-reflect democratic pragmatism. While it is argued that, power is somewhat concentrated in the hands of the few and thus party structures are ignored in terms of decision making have been challenged and received relevant reforms. Areas where high ranking members intend to impose candidates on constituencies or take deci- 
sions devoid of the concerns of the local structures have led to negative returns and, in some cases, caused defeats in elections. Thus, internal party democracy has been a key factor in how parties have become strong and its influence in electoral performance (Owusu Nsiah, 2020a). For instance, in the 2016 election, the NDC lost two strong hold constituencies namely, Lawra and Nandom. Partly, was due to the imposition of candidates who were not favoured by the rank-and-file members at the local arena and thus voted in a "skirt and blouse" manner (Bob-Milliar \& Paller, 2018). In the 2008 the NPP lost the elections as part of the monopoly of power and factionalism, where some candidates were favoured by "party bosses" and others disqualified; campaign teams formed from Accra without the full consent of local structures deviating from the democratic principles. However, prior to the 2016 elections, 8 years later they learnt lessons; upheld party democracy and the local structures played a significant part in terms of a decentralised campaign process and significantly contributed to their victory (Owusu Nsiah, 2020a; Bob-Milliar \& Paller, 2018). In an attempt to re-nominate the incumbent MP, one Mr. Abdallah Bandah in the 2020 elections in an unopposed manner for the Offinso south constituency; the rank-and-file members objected and challenged this decision based on the disappointments of the constituency; due to poor delivery by the MPs twelve year-period in parliament ${ }^{3}$. Eventually he lost the primary elections as he was challenged. There have been several reforms that have sought to increase the number of electorates (delegates) in primary elections as part of democratizing the party (Ichino \& Nathan, 2016).

Significantly, part of the reasons that have made the Ghanaian voter clientelistic and ethnic in terms of electoral choice as have been argued is that: political parties do not present any credible policy commitments, campaigns are issueless and thus the political system is devoid of issue-based politics as have been argued. To accept such claims is to be uncritical of the state of Ghanaian politics years after a recourse to democracy. In almost three decades of multi-party democracy since the return to constitutional rule, Ghana has made significant strides in her electoral politics-campaigns have largely been issue based and thus had influence on the electoral choices of electorates. The NPP-a liberal democratic party, and the NDC-social democratic party, have produced eight manifestoes between 1992 and 2020. These manifestoes are cardinal plans which housed their coherent and broad national programmes that they have at least fulfilled majority of them. And most of these appeals have had influence on the electorates (Ayee, 2011). Ayee (2011) argues that, in the 2000 elections the clarity in NPP's message of "Positive change" which basically revealed how the NDC contributed to economic hardships and bad governance; And thus, provided relevant programmes and prospective policies to ensure social and economic development resonated well with the people and contributed to their victory. Fur${ }^{3}$ Offinso Youth invoke curses on party executives.

https://www.ghanaweb.com/GhanaHomePage/NewsArchive/NPP-primaries-Offinso-NPP-youth-in voke-curses-on-party-executives-971362. 
ther, he argues that, in the 2008 elections, the "NDC"s "I care for you" manifesto message and making poverty reduction the main focus of its campaign promises, touting investment in people, jobs, the economy and making government more transparent and accountable (Ayee, 2011: p. 375), resonated well with the electorates and had impacts in their victory. Even though the documents include short-medium- and long-term plans, the manifestos are largely seen as promises and specific strategic policy initiatives to be implemented within a four-year term (Ayee, 2009). Majority of the broad policies and national programmes that were promised by both the NPP and NDC have been carried out. Ayee (2011), points to the introduction of the National Youth Employment Programme in 2004 which created 108,000 jobs; the introduction of the National Health Insurance Scheme in 2003 to replace the "cash-and-carry", School Feeding Programme, Capitation Grant and Metro Buses; the introduction of the Ghana Education Trust Fund (GET Fund) to support the financing of education and education related expenditure, an expanded and improved national infrastructure, especially in road, port rehabilitation, electricity generation and distribution especially in the rural areas, network. Currently the free senior high school education is ongoing as a broad national policy under the NPP government.

What's more, the build up to the 2016 election revealed significantly, policy and civic debates about the economy. The campaign environment was lively and vibrant as it dealt with purely issued based dynamics, particularly about the economy. Presidential candidates conducted multiple tours around the country during the lengthy campaign with high number of large rallies and town hall meetings (EUEOM, 2016: p. 18). In August and September 2016, the NDC launched its campaign consecutively in two of Ghana's electoral swing regions Cape Coast in the Central region and Sunyani in the Brong Ahafo region respectively. The campaign launch: "Changing Lives and Transforming Ghana". The 78-paged manifesto highlighted the achievements of the NDC (National Democratic Congress, 2016). Obviously and interpretatively the NDC in sum campaigned under the slogan "continuity in change and progressive change"-this was due to the fact that, the campaign was to remind Ghanaians of the NDCs achievements, and thus urged Ghanaians to compare the record of the NDC in office and vis-à-vis that of the other parties especially the NPP (Owusu Nsiah, 2020b). Interestingly, on the $8^{\text {th }}$ of September 2016 at the national theatre, a 67-page report lecture was delivered by Dr. Mahamudu Bawumiah-the then, 2016 NPP Vice-Presidential Candidate but now vice president of the republic of Ghana, on the theme-the state of the economy: a foundation of concrete or straw? The thought-provoking report provided a dissenting view on the state of the economy. With statistical presentation and other macroeconomic indicators, the report showed nothing but the deteriorative state of the economy under the John Mahama led administration". The NPP campaigned under the theme: “Change: creating prosperity \& equal opportunity for all” (Owusu Nsiah, 2020b).

${ }^{4}$ Bawumia delivers lecture on true state of economy today. 
It campaigned against the NDC which it accused of being a corrupt government with legacies of stalling the development of the economy through poor education, health and socio-economic policies, and the mismanagement of state funds. The NPP promised a radical transformation of the national economy, with job creation at the top of its agenda. Its flagship policy of "one dam, one village", "one district, one factory" and the "Free senior high education", improvement in agricultural production in the northern savannah and to give jobs to unemployed youth resonated with the voters. They also adopted a decentralised campaign where local structures identified context specific problems within constituencies that needed to be addressed (Bob-Milliar \& Paller, 2018: p. 20). Through campaign tours and several rallies these two and other minor (Yobo \& Gyampo, 2015) political parties espoused their cardinal plans and thus well-articulated programmes for the ordinary Ghanaian to choose from.

\section{On Voting Intentions}

There is an emergent programmatic politics which significantly is also dependent on the evaluative rationales of electorates. Lindberg and Morrison (2008) in a cross-national survey research found that, clientelism and ethnic voting (non-evaluative rationales) are minor features of the Ghanaian electorate. Ghanaians employ retrospective and prospective evaluations as guiding principles to renew mandates or "throw the rascals out". They assess the socio-economic conidiations and review the policy commitments of parties or politicians before choosing a party or politician to vote for (CDD, 2016; see Figure 1).

Substantiating the programmatic or evaluative nature of electorates, for example, in 2008, Mr. Doe Adjaho, the former MP for Ave-Avenor constituency received open resentments from the youth and promised to vote against him. This was because he had neglected his responsibilities and largely reneged on his developmental promises to improving the lives of people in the constituency ${ }^{5}$.

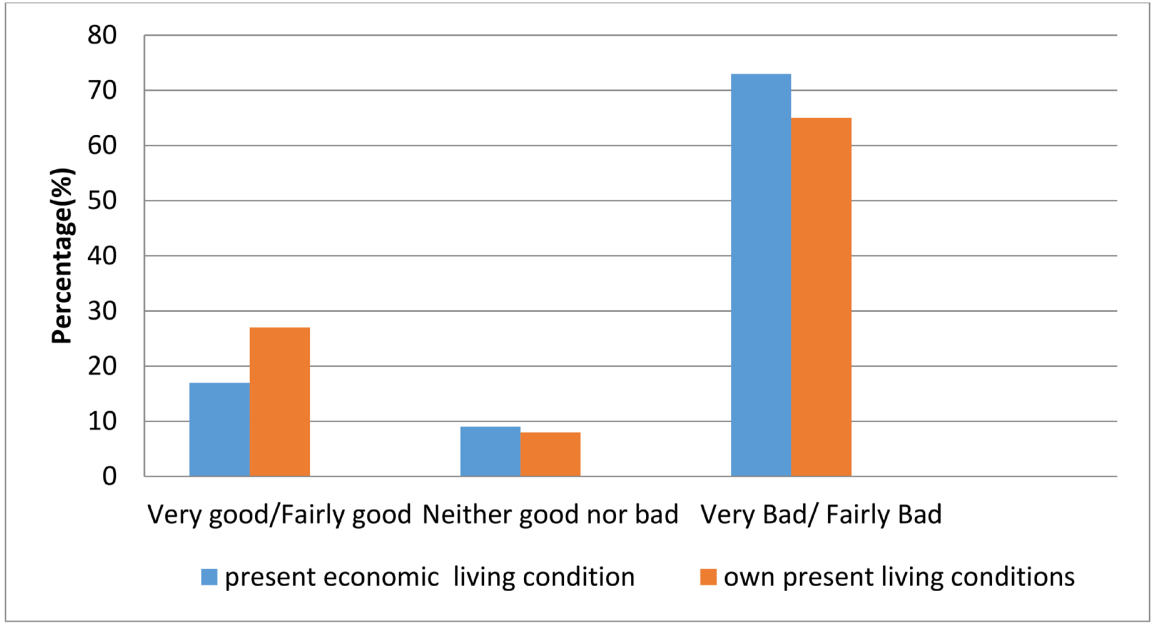

Source: CDD, 2016

Figure 1. Socio-Economic Conditions in the Country, 2016.

${ }^{5}$ Adjaho shunned by enraged youth.

https://www.myjoyonline.com/adjaho-shunned-by-enraged-youth/. 
Hajia Alima Mahama, in her bid to seek re-election in NPP's primaries to retain her seat as the MP for Gambaga-Nalerigu constituency, met the wrath of the constituents. They lamented that; she had not honored the promises on welfare policies and thus neglected the constituency. Thus, they were prepared to throw her out in the primaries ${ }^{6}$. Also, in 2013, the youth of Atwima Nwabiagya south registered their displeasure and disappointments on the poor and careless attitude of their MP, Owusu Bio Benito, towards development and improvement of the lives of the people in the constituency ${ }^{7}$. The volta region has been stereotyped by voting on ethnic lines and nothing else. However, in the build up towards the 2016 elections showed a contradictory spectacle. The chiefs and the youth of volta region criticized the Mahama-led administration for the lack of commitment to tackling developmental issues that confront the people. They strongly decided to prevent any political activity and pledged that their votes will be "decided on issues and issues only". Togbe Afede XIV further added that, politics is not an end in itself; "it must bring development and happiness to the people, not a select few". It must create an opportunity for all, whether in NPP or NDC ${ }^{8}$. For instance in 2016, during the elections, I was engaged in a conversion with one native of the central region who stayed around Oforikrom constituency in the Ashanti region. She said:

The central region is a swing region because both the NPP and NDC dominate over there. However, irrespective of our partisanship what we do is that we totally assess your work and vote (Field notes 2016).

In 2015, 200 NDC youth activists in the Asawase constituency in the Ashanti region (one of NDC's strongholds) "crossed the carpet" to the main opposition NPP. According to these youth, the decision of defection to the NPP was born out of the fact that the NDC was unable to solve the harsh economic situation the country faces and thus saw the NPP as a reliable opposition party. Based on the track records of the NPP it would be a good decision they vote for the NPP in the 2016 elections 9 .

In the CDD's survey on popular opinions conducted across the country which sampled about 2400 respondents in 2016; Ghanaians clearly articulated factors that were likely to influence their voting. An absolute majority of Ghanaians disagreed strongly with voting for parties whose candidates offer gifts, identify with their religious faith and ethnically (see Figure 2). A majority of Ghanaians

\footnotetext{
${ }^{6}$ Nalerigu angry youth chase out Alima Mahama. https://citinewsroom.com/2020/04/nalerigu-angry-youth-allegedly-chase-out-alima-mahama-over-u nfulfilled-promises/.

${ }^{7}$ Angry youth descend on Benito.

https://www.modernghana.com/news/458879/angry-youth-descends-on-atwima-nwabiagya-south.h tml.

${ }^{8}$ Stop calling Volta region your "world bank"-Togbe Afede to NDC.

https://www.pulse.com.gh/news/politics/election-2016-stop-calling-volta-region-your-world-bank-t ogbe-afede-to-ndc/wvylsx7.

${ }^{9}$ NDC Youth in Ashanti region defects to NPP. 200 NDC youth in Ashanti Region defect to NPP (ghanaweb.com).
} 


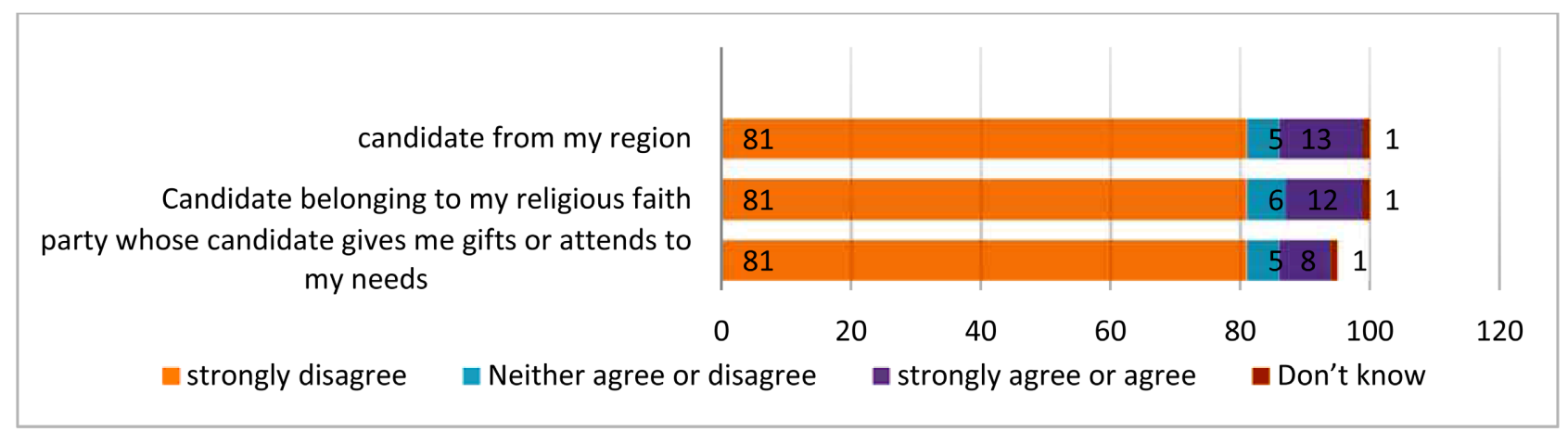

Source: CDD, 2016.

Figure 2. Voting on the basis of regional, religious or personal material benefits.

(57\%) endorse voting for the parliamentary candidate who would make policies that benefit everyone in the country. However, nearly 4 in every 10 Ghanaians say they will vote for candidates who can deliver goods and services to people in their communities (CDD, 2016).

\section{Conclusion}

Africa is a politically polarised continent. Some countries have institutionalised multiparty political systems, where political parties competitively participate in elections. On the other hand, there are a number of authoritarian regimes where ruling elites or dominant parties have entrenched themselves in power for a very long time. Ghana has always remained a beacon of democratic freedom and political excellence and thus a model for sub-Saharan Africa. While existing literature argues that the transition to the democratic system of government has exacerbated neopatrimonial tendencies, this work has argued otherwise. In this work, I have argued that, in almost three decades of democratization, Ghana's political system has embraced institutionalised programmatic politics. In this form of institutionalisation, there is a paradigm shift, where political parties have strong internal party democracy, develop credible programmes and broad policy commitments and engage in civic debates about the economy. More importantly, programmatic politics also depends on the linkage mechanisms between electorates and parties. For programmatic politics, the principals (electorates, voters) are sophisticated, knowledgeable about the state of the economy, their socio-economic status, and make retrospective and prospective evaluations about government, political parties, elected officials (e.g., MPs) before casting their votes. Predominantly, with the pieces of evidence provided, demonstrate that Ghana has a programmatic politics. Yet, there are subtle occurrences of clientelism and, patronage and ethnic voting. But these are minor features in Ghana's body politic.

\section{Conflicts of Interest}

The author declares no conflicts of interest regarding the publication of this paper. 


\section{References}

Abrahamsen, R. (2000). Disciplining Democracy: Development Discourse and Good Governance in Africa. Zed Books.

Aidoo, T. M. (2008). Political Participation, Governance, and Neopatrimonial Rule in Africa: The Case of Ghana (1990-2000). VDM Verlag.

Allen, C. (1995). Understanding African Politics. Review of African Political Economy, 22, 301-320. https://doi.org/10.1080/03056249508704142

Arriola, L. R. (2012). Multi-Ethnic Coalitions in Africa: Business Financing of Opposition Election Campaigns. Cambridge University Press. https://doi.org/10.1017/CBO9781139108553

Arthur, P. (2009). Ethnicity and Electoral Politics in Ghana's Fourth Republic (Essay). Africa Today. https://doi.org/10.2979/AFT.2009.56.2.44

Ayee, J. R. A. (2009). The Evolution of the New Patriotic Party in Ghana. South African Journal of International Affairs, 15, 185-214. https://doi.org/10.1080/10220460802614064

Ayee, J. R. A. (2011). Manifestos and Elections in Ghana's Fourth Republic. South African Journal of International Affairs, 18, 367-384.

https://doi.org/10.1080/10220461.2011.622951

Bates, R. (1981). Markets and States in Tropical Africa: The Political Basis of Agricultural Policies. University of California Press.

Bleck, J., \& Van de Walle, N. (2011). Parties and Issues in Francophone West Africa: Towards a Theory of Non-Mobilization. Democratization, 18, 1125-1145. https://doi.org/10.1080/13510347.2011.603473

Bob-Milliar, G. M. (2011). Political Polarisation in Ghana: Reflections on the 2008 General Election. African Students' Journal, 1, 5-9.

Bob-Milliar, G. M., \& Paller, J. W. (2018). Democratic Ruptures and Electoral Outcomes in Africa: Ghana's 2016 Election. Africa Spectrum, 53, 5-35. https://doi.org/10.1177/000203971805300102

Booth, T., Booth, W., \& McConnell, D. (2006). Temporal Discrimination and Parents with Learning Difficulties in the Child Protection System. The British Journal of Social Work, 36, 997-1015. https://doi.org/10.1093/bjsw/bch401

Bratton, M., \& Van de Walle, N. (1997). Democratic Experiments in Africa. Cambridge University Press. https://doi.org/10.1017/CBO9781139174657

Brobbey, C. A.-B. (2013). Neopatrimonial Logic and National Programmatic Policies in Ghana: A Case of Rice Importation and Production Policies under the Administrations of J.A. Kufuor and J.E.A. Mills. African Journal of Political Science and International Relations, 8, 43-53. https://doi.org/10.5897/AJPSIR12.056

Bryce, J. B. (1921). Modern Democracies. Macmillan and Co.

Carbone, G. M. (2007). Political Parties and Party Systems in Africa: Themes and Research Perspectives. World Political Science, 3, 1-29. https://doi.org/10.2202/1935-6226.1023

Carothers, T. (2006). Confronting the Weakest Link. Aiding Political Parties in New Democracies. Carnegie Endowment for International Peace.

Chabal, P., \& Daloz, J.-P. (1999). Africa Works. Disorder as Political Instrument. James Currey.

Cheeseman, N. (2010). African Elections as Vehicles for Change. Journal of Democracy 
21, 139-153. https://doi.org/10.1353/jod.2010.0019

Cheeseman, N. (2018). Understanding African Politics: Why We Need to Bring the State Back In. In N. Cheeseman (Ed.), Institutions and Democracy in Africa: How the Rules of the Game Shape Political Engagements (pp. 1-39). Cambridge University Press. https://doi.org/10.1017/9781316562888.001

Cheeseman, N. (2019). A Divided Continent-BTI 2018 Regional Report Africa. Bertelsmann Stiftung.

Cheeseman, N., \& Larmer, M. (2015). Ethnopopulism in Africa: Opposition Mobilization in Diverse and Unequal Societies. Democratization, 22, 22-50. https://doi.org/10.1080/13510347.2013.809065

Cheeseman, N., \& Paget, D. (2014). Programmatic Politics in Comparative Perspective. In Cheeseman, N. (Ed.), Politics Meets Policies: The Emergence of Programmatic Political Parties. IDEA.

Cheeseman, N., Pablo, L., Kitschelt, H., Paget, D., \& Rosenblat, F. (2014). Politics Meets Policies: The Emergence of Programmatic Political Parties. IDEA.

Cooper, I. (2018). Political Parties: Presidential Succession Cries and Internal Party Democracy. In N. Cheeseman (Ed.), Institutions and Democracy in Africa: How the Rules of the Game Shape Political Developments (pp. 191-293). Cambridge University Press. https://doi.org/10.1017/9781316562888.008

Cotter, C. P., Gibson, J. L., Bibby, J. F., \& Huckshorn, R. J. (1984). Party Organizations in American Politics. Praeger.

Cowen, M., \& Laakso, L. (2002). Multi-Party Elections in Africa. Palgrave.

Daddieh, C. K., \& Bob-Milliar, G. M. (2012). In Search of "Honorable" Membership: Parliamentary Primaries and Candidate Selection in Ghana. Journal of Asian and African Studies, 47, 2014-2020. https://doi.org/10.1177/0021909611421905

Dalton, R. J. (2014). Citizen Politics: Public Opinion and Political Parties in Advanced Industrial Democracies. Chatham House.

Electoral Commission of Ghana (2004). Presidential and Parliamentary Elections Report. Accra.

Elischer, S. (2013). Political Parties in Africa: Ethnicity and Party Formation. Cambridge University Press. https://doi.org/10.1017/CBO9781139519755

Erdmann, G. (2004). Party Research: Western European Bias and the African Labyrinth. Democratization, 11, 63-87. https://doi.org/10.1080/1351034042000238176

EUEOM (European Union Election Observer Mission) (2016). Report on Ghana Presidential and Parliamentary Election.

Fiorina, M. P. (1981). Retrospective Voting in American National Elections. Yale University Press.

Fomunyoh, C. (2001). Democratization in Fits and Starts. Journal of Democracy, 12, 36-50. https://doi.org/10.1353/jod.2001.0048

Fridy, K. S. (2007). The Elephant, Umbrella, and Quarrelling Cocks: Disaggregating Partisanship in Ghana's Fourth Republic. African Affairs, 106, 281-305.

https://doi.org/10.1093/afraf/adl040

Gadjanova, E. (2017). Electoral Clientelism as Status Affirmation in Africa: Evidence from Ghana. The Journal of Modern African Studies, 55, 593-621.

https://doi.org/10.1017/S0022278X17000416

Ghana Centre for Democratic Development (CDD-Ghana) (2016). Popular Opinions on Issues at Stake in the 2016 Election: Evidence from a CDD-Ghana Survey. August. 
Gunther, R., \& Diamond, L. (2003). Species of Political Parties: A New Typology. Party Politics, 9, 167-199. https://doi.org/10.1177/13540688030092003

Gyampo, R. E. V., Emmanuel, G., \& Yobo, E. (2017). Ghana's 2016 General Election: Accounting for the Monumental Defeat of the National Democratic Congress (NDC). Journal of African Elections, 16, 124-145. https://doi.org/10.20940/JAE/2017/v16i1a2

Gyimah-Boadi, E. (2007). Political Parties, Elections and Patronage: Random Thoughts on Neo-Patrimonialism and African Democratization. In M. Basedau, G. Erdmann, \& A. Mehler (Eds.), Votes, Money and Violence: Political Parties and Elections in Sub-Saharan Africa (pp. 21-33). Nordiska Afrikainstitutet.

Horowitz, D. (2000). Ethnic Groups in Conflict. University of California Press.

Huntington, S. (1991). The Third Wave: Democratization in the Late Twentieth Century. University of Oklahoma Press.

Ichino, N., \& Nathan, N. L. (2016). Democratizing the Party: The Effects of Primary Election Reforms in Ghana. Working Paper 2016.

Jockers, H., Kohnert, D., \& Nugent, P. (2010). The Successful Ghana Election of 2008: A Convenient Myth? Journal of Modern African Studies, 48, 195-115. https://doi.org/10.1017/S0022278X09990231

Key, V. O. (1949). Southern Politics in State and Nation. Vintage.

Kheefer and World Bank (2005). Ghana-Meeting the Challenge of Accelerated and Shared Growth: Country Economic Memorandum, Volume 3. Background Papers, World Bank.

Kitschelt, H. (2000). Linkages between Citizens and Politicians in Democratic Politics. Comparative Political Studies, 33, 845-879.

https://doi.org/10.1177/001041400003300607

Kitschelt, H., \& Wilkinson, S. (Eds.) (2007). Patrons, Clients, and Policies: Patterns of Democratic Accountability and Representation. Cambridge University Press. https://doi.org/10.1017/CBO9780511585869

LeVan, A. C., Page, M. T., \& Ha, Y. (2018). From Terrorism to Talakawa: Explaining Party Turnover in Nigeria's 2015 Elections. Journal Review of African Political Economy, 45, 432-450. https://doi.org/10.1080/03056244.2018.1456415

Lewis-Beck, M., \& Stegmaier, M. (2000) Economic Determinants of Electoral Outcomes, Annual Review of Political Science, 3, 183-219. https://doi.org/10.1146/annurev.polisci.3.1.183

Lindberg, S. (2003). It's Our Time to "Chop": Do Elections in Africa Feed Neo-Patrimonialism Rather than Counter-Act It? Democratization, 10, 121-140. https://doi.org/10.1080/714000118

Lindberg, S. (2006). Democracy and Elections in Africa. John Hopkins University Press.

Lindberg, S. I., \& Morrison, M. K. C. (2008). Are African Voters Really Ethnic or Clientelistic? Survey Evidence from Ghana. Political Science Quarterly, 123, 95-122. https://doi.org/10.1002/j.1538-165X.2008.tb00618.x

National Democratic Congress (2016). Changing Lives, Trans-forming Ghana, 2016 Manifesto. NDC.

Nugent, P. (2001). Winners, Losers and Also Rans: Money, Moral Authority and Voting Patterns in the Ghana Election. African Affairs, 100, 405-428. https://doi.org/10.1093/afraf/100.400.405

Olukoshi, A. O. (1998). Economic Crisis, Multipartyism, and Opposition Politics in Contemporary Africa. In A. Olukoshi (Ed.), The Politics of Opposition in Contemporary Africa (pp. 8-38). Nordiska Afrikainstitutet. 
Oppenheimer, D., \& Edwards, M. (2012). Democracy Despite Itself: Why a System That Shouldn't Work at All Works So Well. MIT Press. https://doi.org/10.7551/mitpress/9195.001.0001

Oquaye, M. (1995). The Ghanaian Elections of 1992-A Dissenting View. African Affairs, 94, 259-275. https://doi.org/10.1093/oxfordjournals.afraf.a098809

Osei, A. (2016). Formal Party Organization and Informal Relations in African Parties: Evidence from Ghana. Journal of Modern African Studies, 54, 37-66. https://doi.org/10.1017/S0022278X15000981

Owusu Nsiah, I. (2020a). Ghana's 2016 Elections: An Overview of Selected Relevant Background Themes. Journal of African Elections, 19, 112-135. https://doi.org/10.20940/JAE/2020/v19i1a6

Owusu Nsiah, I. (2020b). Return of The Elephant from The Bush: The NPP, Organizational Strength and Electoral Success in Ghana's 2016 Election. Ghana Studies, 23, 81-108. https://doi.org/10.1353/ghs.2020.0004

Panebianco, A. (1988). Political Parties: Organization and Power. Cambridge University Press.

Pitcher, M. A. (2012). Party Politics and Economic Reform in Africa's Democracies. Cambridge University Press. https://doi.org/10.1017/CBO9781139014700

Posner, D. (2005). Institutions and Ethnic Politics in Africa. University Press. https://doi.org/10.1017/CBO9780511808661

Randall, V., \& Svåsand, L. (2002). Political Parties and Democratic Consolidation in Africa. Democratization, 9, 30-52. https://doi.org/10.1080/714000266

Resnick, D. (2012). Opposition Parties and the Urban Poor in African Democracies. Comparative Political Studies, 45, 1351-1378. https://doi.org/10.1177/0010414012437166

Riedl, R. B. (2014). Authoritarian Origins of Democratic Party Systems in Africa. Cambridge University Press. https://doi.org/10.1017/CBO9781107045484

Riedl, R. B. (2018). Institutional Legacies: Understanding Multiparty Politics in Historical Perspective. In N. Cheeseman (Ed.), Institutions and Democracy in Africa: How the Rules of the Game Shape Political Developments (pp. 41-60). Cambridge University Press. https://doi.org/10.1017/9781316562888.002

Sartori, G. (1986). The Influence of Electoral Systems: Faulty Laws or Faulty Method? In B. Grofman, \& A. Lijphart (Eds.), Electoral Laws and Their Political Consequences (pp. 43-68). Agathon.

Schattschneider, E. (1942). Party Government. American Government in Action. Farrar and Rinehart.

Schumpeter, J. A. (1942). Socialism, Capitalism and Democracy. Harper and Brothers.

Tavits, M. (2012). Organizing for Success: Party Organizational Strength and Electoral Performance in Postcommunist Europe. Journal of Politics, 74, 83-97. https://doi.org/10.1017/S0022381611001198

Van de Walle, N. (2003). Presidentialism and Clientelism in Africa's Emerging Party Systems. The Journal of Modern African Studies, 41, 297-321.

https://doi.org/10.1017/S0022278X03004269

Van de Walle, N., \& Buttler Smiddy, K. (1999). Political Parties and Party Systems in Africa's Illiberal Democracies. Cambridge Review of International Affairs, 8, 19-21. https://doi.org/10.1080/09557579908400269

Wahman, M. (2014). Democratization and Electoralturnovers in Sub-Saharan Africa and 
Beyond. Democratization, 21, 220-243. https://doi.org/10.1080/13510347.2012.732572

Wantchekon, T. (2003). Clientelism and Voting Behavior: Evidence from a Field Experiment in Benin. World Politics, 55, 399-422. https://doi.org/10.1353/wp.2003.0018

Whitfield, L. (2009). Change for a Better Ghana: Party Competition, Institutionalization and Alternation in Ghana's 2008 Elections. African Affairs, 108, 621-641. https://doi.org/10.1093/afraf/adp056

World Bank (1981). Accelerated Development in Sub-Saharan Africa: An Agenda for Action. World Bank.

Yobo, E., \& Gyampo, R. (2015). Third Parties and Electoral Politics in Ghana's Fourth Republic. Journal of Politics and Law, 8, 7-16. https://doi.org/10.5539/jpl.v8n2p7

Young, D. (2009). Is Clientelism at Work in African Elections? A Study of Voting Behaviour in Kenya and Zambia. Working Paper No. 106, Afrobarometer. 